\title{
Prospects for the Development of Advanced Grain Processing in Russia
}

\author{
Submitted 10/02/20, $1^{\text {st }}$ revision 05/03/20, $2^{\text {nd }}$ revision 30/03/20, accepted 15/04/20
}

\begin{abstract}
A.B. Melnikov ${ }^{1}$, P.V. Mikhailushkin ${ }^{2}$, L.E. Popok ${ }^{3}$
Abstract:

Purpose: The article is devoted to the identifying and evaluating promising areas of advanced grain and legumes processing development as a strategically important area for import substitution and food security of the agribusiness complex.

Methodology/Approach: To achieve this goal, it is necessary to solve the following tasks: the analysis of advanced grain and legumes processing products; the evaluation of the current Russian market for advanced grain processing products; the identification of promising products and directions of the advanced grain processing industry development.

Findings: According to the analysis in this article, this industry is in its infancy, despite the fact that in most developed countries of the world, advanced grain processing is widely elaborated. The key reasons for the Russia's lag there involve the lack of domestic techniques and highly qualified specialists in this field. Processing grain into flour, starches, glucose syrups, biofuels and organic acids makes possible manufacturing plastic and other products. To realize the Russia's potential in manufacturing high-value-added agricultural products, it is necessary to provide state support for investment projects for wheat deep processing through preferential lending and taxation, and co-financing of projects. The strategic goal of the Russian agribusiness in the medium and long term should be changing the structure of manufacturing and export in order to export finished products, but not raw materials.

Practical implications: The results of this research could be introduced in the process of strategic planning of the agribusiness development and import substitution policy in Russia.

Originality/Value: The key contribution of this study lies in the findings of the advanced grain processing industries' analysis in Russia with the regional aspects taken into account.
\end{abstract}

Keywords: Grain and legumes, deep processing, biotechnology, bioethanol, amino acids.

JEL Code: $Q 13, Q 18$.

Paper type: Research article.

${ }^{l}$ D.Sc. in Economics, Professor, Head of the Department of Economics and Foreign

Economic Activity, Kuban State Agrarian University named after I.T. Trubilin, Krasnodar, mikhaylushkinpv@mail.ru ORCID: https://orcid.org/0000-0003-0978-0464

${ }^{2}$ D.Sc. in Economics, Associate Professor, Professor of the Department of Economics and Foreign Economic Activity, Kuban State Agrarian University named after I.T. Trubilin, Krasnodar, mikhaylushkinpv@mail.ru ORCID: https://orcid.org/0000-0003-1304-8102 ${ }^{3}$ Ph.D. in Economics, Associate Professor, Department of Information Systems, Doctoral Candidate at the Department of Economy and Foreign Economic Affairs, Kuban State Agrarian University named after I.T. Trubilin, Lpopok@gmail.com 


\section{Introduction}

The industry of advanced grain processing and leguminous crops is one of the least developed industries in Russian agribusiness, but at the same time, it is very prospective. The need for the import substitution of most of the advanced grain processing products in the domestic market is an incentive for the development of Russian biotechnologies. Domestic consumption of grain (70-74 million tons) and its export (35-40 million tons) determines surplus in grain production (about 10-15 million tons) and the need for its processing.

The purpose of the research is to substantiate the prospects for the development of the advanced grain processing industry in Russia. To achieve this goal, it is necessary to solve the following tasks:

1) the analysis of advanced grain and legumes processing products;

2) the evaluation of the current Russian market for advanced grain processing products;

3) the identification of promising products and directions of the advanced grain processing industry development.

The research object is the advanced grain processing industry in Russia. The research subject is the features of domestic production of advanced grain processing.

\section{Research Methods}

The methodological basis of the research is general scientific methods of cognition, methods of the analysis and synthesis, abstract-logical, comparative, computationalconstructive and monographic methods. The authors utilized data published in open sources and actual statistical data to prepare a comprehensive study and analysis.

\section{Results and Discussion}

The main directions of the grain use in our country are forage, seeds, processing and export. At the same time, most of the grain products, about $60 \%$, is sent for processing. Advanced grain processing is the separation and the effective use of its components such as starch, gluten and other by-products, which are in demand both in the domestic and foreign markets. Various grain crops such as wheat, barley, rye, oats, corn, triticale could be used as raw materials (Altukhov, 2013; Gurnovich, 2019).

These products are utilized in food and other industries. This industry is now in its infancy stage in Russia, despite the fact that it is widely eleborated in most developed countries of the world. High capital intensity of construction and significant technological risks, lack of qualified specialists slow down this process (Eremchenko, 2017). 
The most important factors for the advanced grain processing development are as follows:

1) the import dependence of Russia on advanced grain processing products with high added value;

2) the livestock industry intensification by increasing the nutritional value of the feed base (Bulavin, 2013);

3) the ability to enter world markets with high-margin products;

4) a surplus of grain production in some regions of the country;

5) the need to meet domestic demand for advanced grain processing products (Agroinvestor, 2019).

The export of grain as raw materials is much cheaper for agricultural producers than high-margin products such as glucose, starch, amino acids. That prevents the advanced grain processing development. At the same time, Russia's import dependence on some types of these products is almost 100\% (Ablaev, 2016).

Grain processing products consist of three levels:

- the first stage products (starch);

- the second stage products (glucose, gluten, glucose-fruit syrups);

- the third stage products (amino acids, vitamins, and bioethanol) (Gurnovich, 2019).

The manufacture marginality increases from one level to another. Mainly, Russia produces starch. The first stage of advanced grain processing is producing starches. Manufacturing starch treacle products in Russia includes products such as feed additives made of wheat and corn grinding, yeast proteins, starch molasses and native starches. Figure 1 shows the volume of processing and export of these products by Russian manufacturers in 2018 (Bulavin, 2017). Most of the starch products manufactured by Russia, are feed supplements $(2.1$ million tons, including 0.8 million tons for export). In 2018 the yeast protein production was 0.331 million tons, 0.143 million tons were exported. Starch molasses and native starches are produced in small amounts ( 0.57 and 0.28 million tons).

In Russia, there are about 30 manufacturers of starch treacle products, which annually process 1.5 million tons of cereals and legumes, including 1 million tons of corn, 500 thousand tons of wheat. The largest producers in this industry are Cargill, Amilco and Rosva (Table 1).

In 2020, sugar and starch products of the French company Tereos are planned to enter the Russian market, running 3 plants in Russia for manufacturing starch and starch products. The most promising products are native starch, glucose, amino and organic acids. 
Figure 1. Production and export of starch products in Russia in 2018, million tons (Bulavin, 2017).

$$
2,5
$$

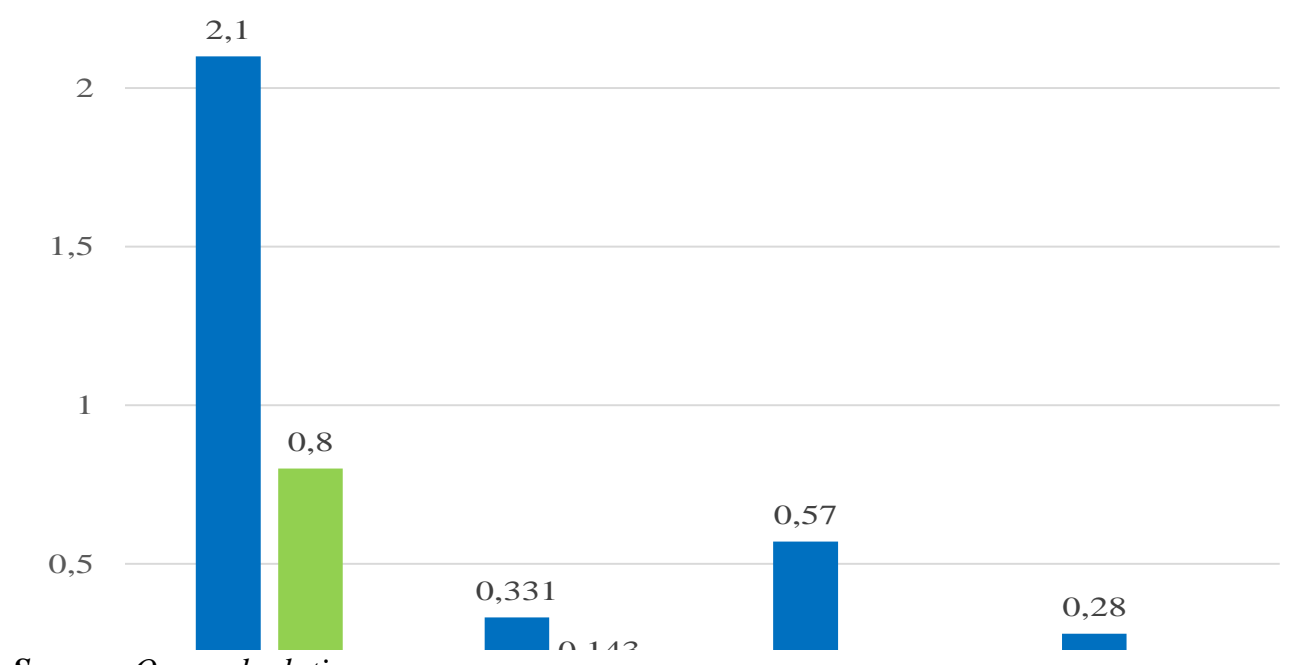

Source: Own calculations.

Table 1. The largest producers of starch products in Russia (Gurnovich, 2019).

\begin{tabular}{|l|l|l|}
\hline No & Name and location & $\begin{array}{l}\text { Processing } \\
\text { thousand tons }\end{array}$ \\
\hline 1. & Cargill (Tula Region) & 500 \\
\hline 2. & Rosva (Kaluga Region) & 250 \\
\hline 3. & Amilco (Rostov Region) & 200 \\
\hline
\end{tabular}

\section{Source: Own calculations.}

In contrast to the second-stage products, the volume of which is increasing annually in the Russian market, biotechnological products obtained during the third stage still are only planned for manufacturing.

In the structure of the third stage grain processing products, the amino acid lysine occupies the main place. The domestic production of lysine covers only half of domestic demand, despite the fact that its volume is increasing annually. The largest producers of this amino acid are "Donbiotech", "Premix Plant No 1", "Aminosib". It is also planned to launch some more investing projects that will satisfy the demand for leasing in Russia (Agroinvestor, 2019). For Russia one more promising advanced grain processing product is wheat gluten. By 2024, it is planned to increase the annual consumption of gluten by $4 \%$ and increase its production to 165 thousand tons.

Bioethanol is an advanced grain processing product (necessary for alternative energy), the demand for which is growing quickly all over the world (Paptsov et al., 
2019). In order to satisfy this demand it is necessary to increase grain production by 10-15 million tons annually (Tetzoev, 2016).

In Russia, companies such as Saratov biotechnologies and Microdynamic technologies plan to produce bioethanol. Most of these products will be exported. In addition, Saratov biotechnologies plans to produce raw materials for bioplastics. In conditions of increasing environmental problems, biodegradable plastic is a product in demand in developed European countries. Lipetsk Region ran the construction of the grain processing plant for the production of biopolymers, biomonomers and bioplastics in 2019 (Agroinvestor, 2019).

Krasnodar Region is one of the most promising regions of the Russian Federation in increasing the volume of grain processing. In 2018 export of agricultural products of the Krasnodar agribusiness amounted to 2.2 billion dollars, including 1.76 billion for raw materials $(80 \%)$. It is necessary to change this ratio and to increase export of products with high added value (Polovchenko, 2014). Also it must be admitted that regions of the Siberian and Volga Federal districts are landlocked and far away from the main grain markets. These conditions create windows of opportunity for the deep processing industry. In order to avoid high transport and logistics costs of exported products, plants for advanced grain processing should be constructed here. One of these regions is the Novosibirsk region, where a surplus of produced grain is spotted. This will provide the local food and livestock industry with raw materials.

According to the Ministry of agriculture, by 2035 the potential to increase manufacturing advanced grain processing products is about $\$ 1.3$ billion. According to the "Long-Term strategy for the Russia's grain complex development for 20162025 and up to 2030", it is planned to increase industrial grain processing to 10.6 million tons annually by 2030, including 5 million tons of deeply processed grain for the production of native and modified starches, glucose-fructose syrups, organic acids, bioethanol and other biochemical products.

According to the forecast of the Russian biofuel Association, in the long term it is possible to increase export of deeply processed grain to 21 million tons, including 3 million tons for flour milling industry, 2 million tons for amino acids, vitamins and sorbitol, 6 million tons for bioethanol and other types of biofuels, 9 million tons for organic acids.

The priority directions in increasing the production of agricultural products for Russia are grain, fat and oil products, sugar, flour and cereals and starch products (Tyupakov et al., 2019). Processing grain into flour, starches, glucose syrups, biofuels and organic acids makes it possible to produce plastic and other products. The main risks in advanced grain processing are the following:

1) the lack of domestic manufacturers of equipment for processing plants;

2) difficulties in determining the product (inability to concentrate on a specific 
monoproduct) and in finding sales markets (Eremchenko, 2017);

3) the lack of qualified specialists in the field of biotechnology;

4) the lack of domestic experience in production techniques;

5) in most of Russia's territories, due to natural and climatic conditions, it is impossible to grow crops used for products, such as bioethanol.

To realize the potential of Russia in high-value-added agricultural products, agribusiness needs state support for investing projects of deep wheat processing (manufacturing starch products and biopolymers for bioplastics) (MA RF, 2019). It makes it possible to solve a few tasks simultaneously: import substitution of deep processing products in the Russian market, food security, increasing export supplies. It is necessary to develop the advanced grain processing industry together with chemical, microbiological and pharmaceutical ones. The strategic goal of the agribusiness in the nearest future should be changing the structure of production and export. It is important to increase export of finished products, not raw materials. The increasing number of companies engaged in high-tech processing and industrial biotechnologies will lead to the creation of a resource base for other industries, food security in Russia and the development of scientific potential.

\section{Conclusions}

Thus, advanced grain processing is one of the most significant and promising areas of the domestic agribusiness development. The main factor in the advanced grain processing development is the intensive animal husbandry development, which leads to increasing the production of compound feeds. Currently, most of raw materials for compound feeds are supplied from abroad. The feed industry development causes the need for amino acids. All this requires the development of the domestic advanced grain processing industry. The state needs to create conditions for investment in the industry in order to build new plants using tools such as preferential lending, taxation, co-financing, etc.

The advantages of this industry development are new working places, the creation of high-tech industries, import substitution, food security of the country, access to world markets with high-margin products. It is necessary to stop grain crops overproduction in the domestic market (by sending the surplus to processing) that will help to smooth out price fluctuations for products during periods of high harvest. For Russia, the most promising products for advanced grain and legumes processing are starches (for food, pulp and paper, pharmaceutical and other industries), lysine (for poultry and pig industries), bioplastics with bioethanol.

\section{References:}

Ablaev, A.R. 2016. Export of advanced grain processing products: three steps for growth. Available at: http://www.graintek.ru/Graintek\%20\%202016/Ablaev\%20Grain\%20Forum\%20-\%20export\%202016\%20-\%20final.pdf 
Agroinvestor. 2019. Difficulties of redistribution. What hinders the of advanced grain processing development. Available at: https://www.agroinvestor.ru/analytics/article/32529-trudnosti-peredela/.

Altukhov, A.I. 2013. Grain farming and the grain market of Russia. Economics of Agriculture in Russia, 5, 32-4.

Bulavin, R.E. 2017. Advanced grain processing. Russian Grain Union, available at: http://grun.ru/upload/news/2017/Статья\%20в\%20\%20ХлПр\%2009.17\%20Булавин. $\% 20$ Переработка.pdf.

Eremchenko, O.A. 2017. Technological barriers to increase the export potential of the Russian grain industry. Economics of science, 1, 40-43.

Gurnovich, T.G. 2019. Advanced grain processing is a strategic direction of the agroindustrial complex development in Russia. The Economy Vector, 10(40), 51.

Jarkova, I., Slepokurova, J., Alekhina, N., Samokhvalov, A. 2018. Ecological, biotechnological and economic aspects of wheat grain processing. IOP Conference Series, Earth \& Environmental Sciences, 337, doi:10.1088/1755-1315/337/1/012031.

MARF. 2019. Ministry of agriculture of the RF will develop new measures to support grain processing by the end of 2019. Available at: https://exp.idk.ru/news/politika/mskh-rfk-koncu-2019-goda-razrabotaet-novye-mery-podderzhki-pererabotki-zerna/488265/.

Paptsov, A.G. Altukhov, A.I. Kashevarov, N.I. 2019. Forecast of the crop production industry scientific and technological development, including seed production and organic agriculture in Russia, in the period up to 2030. Novosibirsk State University, Publishing house of NSAU "Zolotoy Kolos", 100.

Polovchenko, M.A. 2014. Foreign economic activity specifics of the Krasnodar Region and its impact on the ability of the region to ensure food security of the country. Available at: https://cyberleninka.ru/article/n/spetsifika-vneshneekonomicheskoy-deyatelnostikrasnodarskogo-kraya-i-eyo-vliyanie-na-vozmozhnost-obespecheniya-regionom.

Solovey, I. 2017. Analysis of economic efficiency of grain production of main food and grain-forage crops in the region. EUREKA: Social Sciences and Humanities, 6, 23-26.

Tetzoev, A.G. 2016. Prospects for the bioethanol industry development in Russia. Management consulting, 6 (90), 117-119.

Tyupakov, K.E., Reznichenko, S.M., Shichiyakh, R.A. 2019. Priority Directions for Regional Grain Market Development. International Journal of Engineering and Advanced Technology (IJEAT), 1(9), 3385-3387.

Verkhovtsev, A.A. 2019. Priority directions of the grain market strategic development. Ministry of agriculture, 1, 56-59.

Zhidkov, S.A. 2018. Priority directions of the grain market development in Russia. Michurinsk publ., 313. 